\title{
Dissimilatory nitrate reduction to ammonium (DNRA) as a nitrogen link, versus denitrification as a sink in a shallow estuary (Laguna Madre/Baffin Bay, Texas)
}

\author{
Soonmo An*, Wayne S. Gardner
}

The University of Texas at Austin, Marine Science Institute, 750 Channel View Drive, Port Aransas, Texas 78373, USA

\begin{abstract}
Rates of nitrate $\left(\mathrm{NO}_{3}^{-}\right)$reduction to nitrogen gas $\left(\mathrm{N}_{2}\right)$ and ammonium $\left(\mathrm{NH}_{4}^{+}\right)$were measured in August and December 1999 on intact cores (Laguna Madre and Baffin Bay, Texas) using flowing seawater enriched with ${ }^{15} \mathrm{NO}_{3}{ }^{-}$. The combination of membrane inlet mass spectrometry (MIMS) and high performance liquid chromatography (HPLC) allowed accurate and simple estimation of these 2 dissimilatory pathways of $\mathrm{NO}_{3}{ }^{-}$reduction. $\mathrm{NO}_{3}{ }^{-}$enrichment $\left(\sim 100 \mu \mathrm{M}^{15} \mathrm{NO}_{3}{ }^{-}\right)$did not stimulate denitrification (mean $\pm \mathrm{SE}=55 \pm 16$ and $69 \pm 15$ [Aug 99], $-11 \pm 16$ and $11 \pm 18$ [Dec 99] $\mu \mathrm{molN} \mathrm{m}{ }^{-2} \mathrm{~h}^{-1}$ before and after ${ }^{15} \mathrm{NO}_{3}{ }^{-}$addition, respectively; $\mathrm{n}=8$ ). However, ${ }^{15} \mathrm{NH}_{4}{ }^{+}$production rates increased after the ${ }^{15} \mathrm{NO}_{3}{ }^{-}$addition $\left(69 \pm 14\right.$ [Aug 99], $50 \pm 9$ [Dec 99] $\left.\mu \mathrm{mol} \mathrm{N} \mathrm{m}^{-2} \mathrm{~h}^{-1}\right)$, comprised about $1 / 3$ of total $\mathrm{NH}_{4}{ }^{+}$flux, and were comparable to denitrification rates. A larger portion of added ${ }^{15} \mathrm{NO}_{3}{ }^{-}$was converted to ${ }^{15} \mathrm{NH}_{4}{ }^{+}(15$ to $75 \%)$ than to $\mathrm{N}_{2}\left({ }^{29+30} \mathrm{~N}_{2} ; 5\right.$ to $\left.29 \%\right)$ on both sampling dates. High dissimilatory $\mathrm{NO}_{3}{ }^{-}$reduction to $\mathrm{NH}_{4}{ }^{+}$(DNRA) and low denitrification suggest that sulfide may influence the processes. High sulfide concentrations inhibit nitrification and denitrification but may enhance DNRA by providing an electron donor. Inhibited denitrification and enhanced DNRA may preserve available nitrogen in Laguna Madre/Baffin Bay, which has limited water exchange with other bodies of water.
\end{abstract}

KEY WORDS: Dissimilatory nitrate reduction to ammonium - DNRA - Denitrification · Brown tide · Nitrogen conservation · Laguna Madre/Baffin Bay

\section{INTRODUCTION}

The relative partitioning between the 2 major pathways of nitrate $\left(\mathrm{NO}_{3}^{-}\right)$reduction can help determine the degree of available nitrogen $(\mathrm{N})$ conservation in shallow estuaries (Tiedje et al. 1982, Sørensen 1987, Jørgensen 1989, Patrick et al. 1996, Tobias et al. 2001). When $\mathrm{NO}_{3}{ }^{-}$is consumed by denitrification, 'total available' $\mathrm{N}$ is decreased since the final product ( $\mathrm{N}_{2}$ gas) is less available for biological production than ammonium $\left(\mathrm{NH}_{4}{ }^{+}\right)$or $\mathrm{NO}_{3}{ }^{-}$(Howarth et al. 1988). However, if $\mathrm{NO}_{3}{ }^{-}$is used during dissimilatory $\mathrm{NO}_{3}{ }^{-}$reduction to

*Present address: Kyungnam University, Department of Environmental Engineering, Masan, Kyungnam, South Korea 631-701. E-mail: sman@kyungnam.ac.kr
$\mathrm{NH}_{4}{ }^{+}$(DNRA), $\mathrm{N}$ will be conserved in a form that is available to organisms (Koike \& Hattori 1978, Jørgensen 1989, Patrick et al. 1996). Although the occurrence of DNRA has been demonstrated in marine sediments (e.g. Koike \& Hattori 1978, Sørensen 1978, Tobias et al. 2001), the ecological significance of the process is not understood (Sørensen 1987, Cornwell et al. 1999). DNRA rates may be as high as denitrification in shallow estuaries and tidal flat sediments (Koike \& Hattori 1978, Kasper 1983, Jørgensen 1989, Rysgaard et al. 1996, Bonin et al. 1998, Tobias et al. 2001).

Laguna Madre/Baffin Bay is the largest estuary in Texas but receives no major river discharges. Despite the lack of known nutrient inputs, this region is nutrient replete and has suffered from a long lasting bloom of Texas Brown Tide. This monospecific algal bloom of 
Aureomonas lagunensis started in January 1989 and continued for about a decade (Buskey et al. 1998), causing a decline in seagrasses and other benthic fauna (Montagna \& Kalke 1995). The persistence of an algal bloom in this area is unusual and the cause of the bloom is not fully understood. A. lagunensis has the unique characteristic of being able to use $\mathrm{NH}_{4}{ }^{+}$or $\mathrm{NO}_{2}^{-}$ but not $\mathrm{NO}_{3}{ }^{-}$as a nitrogen source (DeYoe \& Suttle 1994). We hypothesize that $A$. lagunensis can outcompete other autotrophs in this system because of its reliance on reduced $\mathrm{N}$ forms. The DNRA mechanism, by supplying $\mathrm{NH}_{4}{ }^{+}$, could help explain the success of Texas Brown Tide.

One reason that DNRA is not understood fully in coastal systems is that methods have been inconvenient. Using ${ }^{15} \mathrm{NO}_{3}{ }^{-}$as a tracer and measuring ${ }^{15} \mathrm{NH}_{4}{ }^{+}$ production rates (for DNRA) have required extensive equipment and effort (Sørensen 1987, Jørgensen 1989, Binnerup et al. 1992, Bonin et al. 1998). Although acetylene inhibition for denitrification measurement is simple and sensitive, problems are associated with the technique including its inhibition of coupled nitrification-denitrification (Knowles 1990). Membrane inlet mass spectrometry (MIMS) allows accurate and simple measurement of $\mathrm{N}_{2}$ :Ar changes due to denitrification (Kana et al. 1994). In this study, we expanded the capability of this technique by measuring different isotopic forms of $\mathrm{N}_{2}$ gas $\left({ }^{29} \mathrm{~N}_{2}={ }^{14} \mathrm{~N}+{ }^{15} \mathrm{~N}\right.$ and $\left.{ }^{30} \mathrm{~N}_{2}={ }^{15} \mathrm{~N}+{ }^{15} \mathrm{~N}\right)$ relative to $\mathrm{Ar}$ (An et al. 2001). The modified setup allowed mechanistic experiments involving ${ }^{15} \mathrm{NO}_{3}{ }^{-}$ addition to be conducted. By adding the tracer, the denitrification measurement estimated from the $\mathrm{N}_{2}$ : $\mathrm{Ar}$ ratio can be verified with an isotope pairing technique (Nielson 1992). In addition, the simultaneous measurement of $\mathrm{N}$ fixation and denitrification is feasible (An et al. 2001). Using the modified MIMS and high performance liquid chromatography (HPLC) to measure ${ }^{15} \mathrm{NH}_{4}{ }^{+}$in water samples (Gardner et al. 1995), we could measure the 2 major $\mathrm{NO}_{3}{ }^{-}$reduction processes (denitrification and potential DNRA) in Laguna Madre/Baffin Bay with a flow-through sediment incubation chamber (Kana et al. 1994, Lavrentyev et al. 2000). Here, we report the results of sediment incubation experiments conducted in August and December 1999 and discuss the potential interaction between the fate of $\mathrm{NO}_{3}{ }^{-}$and the presence of sulfide, which occurs in the study region.

\section{MATERIALS AND METHODS}

Laguna Madre/Baffin Bay is a shallow, semi-enclosed estuary located in southern Texas. Water exchange with the Gulf of Mexico is limited and it is a negative estuary where freshwater input is less than evaporation (residence time $=1 \mathrm{yr}$ ). The salinity is often more than 40 ppt and may reach up to 60 ppt (Buskey et al. 1998). Four stations in Laguna Madre and Baffin Bay were selected to measure water column characteristics (temperature, salinity and dissolved oxygen using a Hydrolab ${ }^{\circledR}$ ) and conduct sediment core incubation experiments (Fig. 1). Stn B24 in Baffin Bay has a depth of $2.2 \mathrm{~m}$ and represents the deepest part of the bay. Stn B6 is shallow and the salinity of the overlying water was higher than B24. The sediment type at Stn B24 is fine clay, whereas Stn B6 has a high sand content (Table 1). The water depths at Laguna Madre stations were between 0.8 and $0.9 \mathrm{~m}$ and did not show spatial variability. Laguna Madre stations were populated with Thalassia testudinum (300 to 600 shoots $\mathrm{m}^{-2}$; Lee \& Dunton 1999). Sand content was highest at Stn L155 among study sites (Table 1). Stn L189 had higher sand content than Stn B24 but lower than Stn B6. During our sampling period, salinity was lower than observed by Buskey et al. (1998) and did not exceed 40 ppt (Table 1). Bottom water was oxygenated at most stations due to winddriven mixing, but oxygen concentrations were low in Baffin Bay during the summer, perhaps because of ground water (low salinity, low oxygen and high $\mathrm{NO}_{3}{ }^{-}$ water) intrusion rather than increased sediment oxygen demand (Dr. D. Brock, Texas Water Development Board, pers. comm.). Baffin Bay salinity was lower in bottom versus surface water at this time.

Undisturbed sediment cores $(7.6 \mathrm{~cm}$ diameter, $30 \mathrm{~cm}$ length; $4 \mathrm{Stn}^{-1}$ ) with bottom water were collected using SCUBA gear. Within $3 \mathrm{~h}$ of collection, the cores were transported to the laboratory and a flow-through plunger with Teflon inlet and outlet tubes was installed

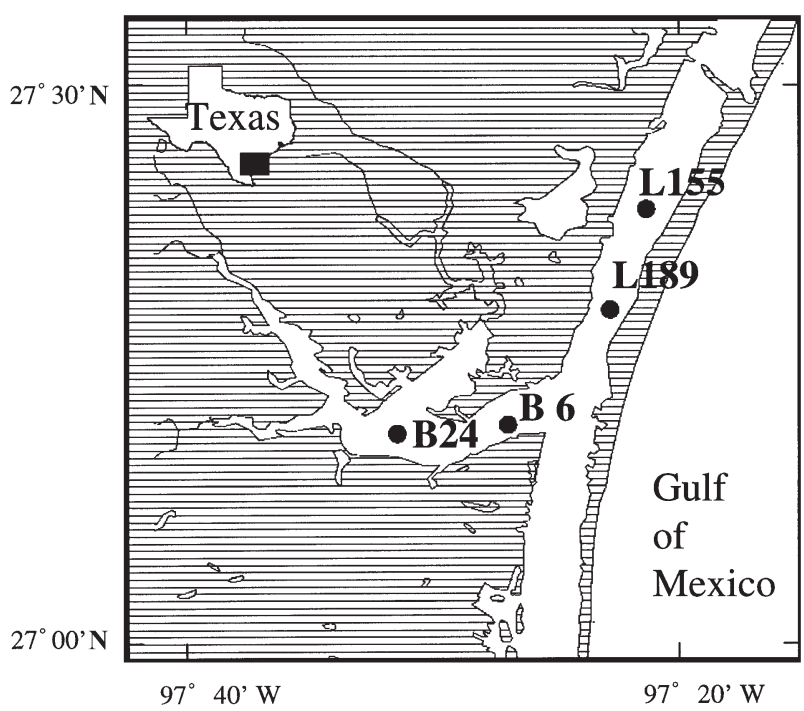

Fig. 1. Sampling stations in Baffin Bay (B6, B24) and Laguna Madre (L155, L189) 
Table 1. Location and environmental variables in Laguna Madre (L155 and L189) and Baffin Bay (B6 and B24) in August and December 1999

\begin{tabular}{|c|c|c|c|c|c|c|c|c|}
\hline & \multicolumn{2}{|c|}{ B6 } & \multicolumn{2}{|c|}{ B24 } & \multicolumn{2}{|c|}{ L155 } & \multicolumn{2}{|l|}{ L189 } \\
\hline & Aug & Dec & Aug & Dec & Aug & Dec & Aug & Dec \\
\hline \multicolumn{9}{|l|}{ Location } \\
\hline Longitude (W) & 97.25 .39 .9 & & 97.33 .11 .1 & & 97.21 .25 .1 & & 97.23 .17 .7 & \\
\hline Latitude (N) & 27.16 .46 .7 & & 27.15 .47 .6 & & 27.24 .34 .2 & & 27.20 .53 .1 & \\
\hline Water depth (m) & 2.2 & & 1.8 & & 0.8 & & 0.9 & \\
\hline Sand content $(\% ;>64 \mu \mathrm{m})$ & 33.9 & & 5.2 & & 72.4 & & 12.1 & \\
\hline \multicolumn{9}{|l|}{ Salinity (ppt) } \\
\hline Surface & 35.23 & 30.04 & 31.6 & 25.67 & 38.07 & 31.94 & 37.18 & 30.52 \\
\hline Bottom & 19.2 & 30.05 & 24.11 & 25.72 & 38.14 & 32.09 & 37.34 & 31.37 \\
\hline \multicolumn{9}{|l|}{ Temperature $\left({ }^{\circ} \mathrm{C}\right)$} \\
\hline Surface & 31.06 & 16.21 & 30.62 & 15.8 & 30.18 & 16 & 29.54 & 15.64 \\
\hline Bottom & 30.75 & 16.19 & 30.36 & 15.75 & 30.22 & 15.59 & 29.56 & 15.79 \\
\hline \multicolumn{9}{|l|}{ Dissolved oxygen $\left(\mathrm{mg} \mathrm{l}^{-1}\right)$} \\
\hline Surface & 5.77 & 7.66 & 5.5 & 6.95 & 5.35 & 6.58 & 4.66 & 6.76 \\
\hline Bottom & 1.35 & 7.09 & 4.28 & 5.61 & 5.32 & 5.88 & 4.53 & 6.33 \\
\hline \multicolumn{9}{|l|}{$\mathrm{NO}_{3}{ }^{-}$concentration $(\mu \mathrm{M})$} \\
\hline Surface & 0.72 & 0.12 & 0.65 & 0.13 & 0.58 & 0.58 & 0.57 & 0.56 \\
\hline Bottom & 6.24 & 1.58 & 22.4 & 5.42 & 0.53 & 0.51 & 0.51 & 0.63 \\
\hline
\end{tabular}

over each sediment core (Lavrentyev et al. 2000). The flow-through chamber setup consisted of an intake water vessel, Teflon flow tubes, a peristaltic pump, a temperature controlled incubation bath and a sample collection vessel. Sediment cores were placed in the incubation bath at in situ temperature, and bottom water collected from the site was passed over the core surface at a rate of $1.2 \mathrm{ml} \mathrm{min}{ }^{-1}$. Half of the cores were incubated under dim light $\left(\sim 30 \mu \mathrm{E} \mathrm{m} \mathrm{m}^{-2} \mathrm{~s}^{-1}=\right.$ average light intensity in Baffin Bay; An \& Gardner 2000) while the others were wrapped with aluminum foil. Water column depth over the sediment was $\sim 5 \mathrm{~cm}$ to give a water volume of $\sim 570 \mathrm{ml}$ in each core. After the cores were incubated for $1 \mathrm{~d}$ to allow steady-state conditions to develop, triplicate samples of feed and outlet water were collected at intervals for dissolved gas analysis. Additional water samples were collected for analysis of dissolved inorganic nitrogen compounds $\left(\mathrm{NH}_{4}{ }^{+}, \mathrm{NO}_{3}{ }^{-}\right.$ and $\mathrm{NO}_{2}^{-}$) using an automated Lachat FIA analyser.

After the 1st or 2nd day of sampling, feed water was enriched with ${ }^{15} \mathrm{NO}_{3}{ }^{-}$(99 at. $\%{ }^{15} \mathrm{~N}_{;} \mathrm{K}^{15} \mathrm{NO}_{3}$ from Aldrich USA) and the concentrations of ${ }^{28} \mathrm{~N}_{2},{ }^{29} \mathrm{~N}_{2},{ }^{30} \mathrm{~N}_{2}$ and ${ }^{15} \mathrm{NH}_{4}{ }^{+}$were measured in inflow and outflow waters. During denitrification, 3 different masses of $\mathrm{N}_{2}$ gas can be produced $\left({ }^{28} \mathrm{~N}_{2}\right.$ from ${ }^{14} \mathrm{NO}_{3}{ }^{-},{ }^{30} \mathrm{~N}_{2}$ from ${ }^{15} \mathrm{NO}_{3}{ }^{-}$, and ${ }^{29} \mathrm{~N}_{2}$ from ${ }^{14} \mathrm{NO}_{3}{ }^{-}$and ${ }^{15} \mathrm{NO}_{3}{ }^{-}$; Nielson 1992). Dissolved $\mathrm{N}_{2}, \mathrm{O}_{2}$ and Ar were measured by MIMS using methods modified from Kana et al. (1994) and described in An et al. (2001). The MIMS is equipped with quadruple mass spectrometer detection via a Channeltron/Faraday secondary electron multiplier (Balzers ${ }^{\circledR}$ Prisma QME 200). By using MIMS and Ar as an internal standard, errors associated with dissolved gas extraction and atmospheric contamination are reduced. The MIMS procedure is also fast, simple and precise (Kana et al. 1994). We modified the method of Kana et al. (1994) to measure dissolved ${ }^{29} \mathrm{~N}_{2}$ and ${ }^{30} \mathrm{~N}_{2}$ in addition to $\mathrm{Ar}, \mathrm{O}_{2}$ and ${ }^{28} \mathrm{~N}_{2}$ (An et al. 2001). The ${ }^{29} \mathrm{~N}_{2}$ and ${ }^{30} \mathrm{~N}_{2}$ concentrations were obtained from the 'excess' atomic mass unit (amu) 29 and 30 signals, respectively, caused by the conversion of added ${ }^{15} \mathrm{NO}_{3}{ }^{-}$. The ratio between ${ }^{29} \mathrm{~N}_{2}$ and ${ }^{28} \mathrm{~N}_{2}$ is $0.00732(0.00366 \times 2)$ in natural samples, considering that the natural abundance of ${ }^{15} \mathrm{~N}$ is $0.366 \%$ (Lide 1992). The relationship between ${ }^{29} \mathrm{~N}_{2}$ and ${ }^{28} \mathrm{~N}_{2}$ concentrations was obtained from standard water (30 ppt artificial seawater held at 21 and $30^{\circ} \mathrm{C}$; Fig. 2a). This relationship was used to determine the excess amu 29 in a water sample. The feed water does not have excess amu 29 resulting from ${ }^{29} \mathrm{~N}_{2}$ while outflow water has excess amu 29 indicating the presence of ${ }^{29} \mathrm{~N}_{2}$ produced during denitrification (Fig. 2a). The excess amu 29 signal was converted to excess ${ }^{29} \mathrm{~N}_{2}$ concentration by comparing results with those from standard water. The $\mathrm{NO}^{+}$ions (amu 30) formed from $\mathrm{N}_{2}$ and $\mathrm{O}^{+}$inside the mass spectrometer caused a linear relationship between amu 30 and (amu $28 \times$ amu 32) ${ }^{0.5}$ (Jensen et al. 
(a) AMU 28 vs. AMU 29

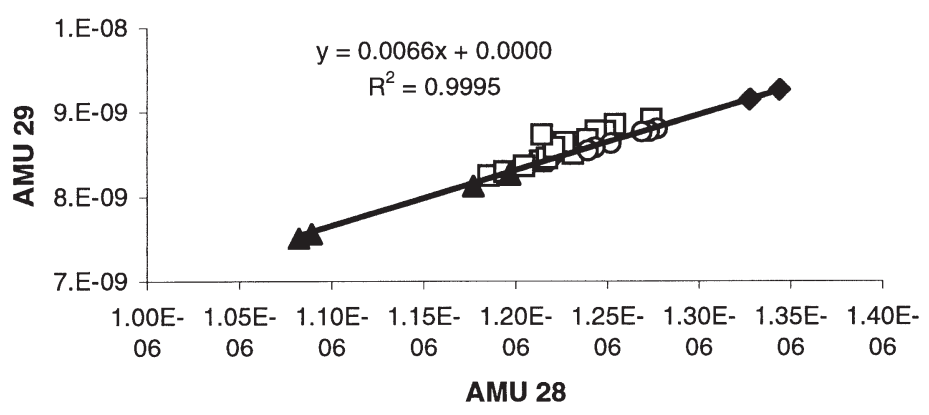

$\begin{array}{ll}\text { (b) } \sqrt{A M U 28 \times A M U 32} & \text { vs. AMU-30 }\end{array}$

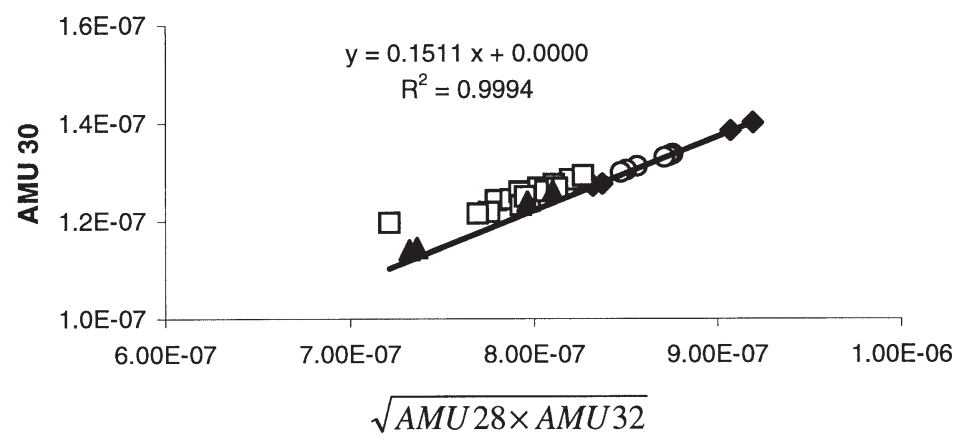

Fig. 2. Relationship between different atomic mass unit (amu) signals in liquid samples measured with a quadruple mass spectrometer. The solid symbol represents standard water ( $\square$ : $30 \mathrm{ppt}, 21^{\circ} \mathrm{C} ; \boldsymbol{\Delta}: 30 \mathrm{ppt}, 30^{\circ} \mathrm{C}$ ) hollow symbols represents samples ( $\square$ : outflow water; $\bigcirc$ : inflow water). The line represents the regression among the standard water. (a) amu 28 versus amu 29 signal, (b) $\sqrt{\text { amu } 28 \times \text { amu } 32}$ versus amu 30 signal. The signal represents partial pressure of the particular gas (mbar) in the mass spectrometer

1996). Jensen et al. (1996) suggested that a linear relationship occurs between amu 30 and (amu $28 \times$ amu 32 ), but we found that (amu $28 \times$ amu 32$)^{0.5}$ exhibited a better regression with amu 30 than (amu $28 \times$ amu 32) (Fig. 2b, taken from An et al. 2001). If oxygen (O) and $\mathrm{N}$ atoms are combined randomly as $\mathrm{N}_{2}, \mathrm{NO}$ and $\mathrm{O}_{2}$, and the proportions $\mathrm{O}$ and $\mathrm{N}$ are $p$ and $q$, respectively, then the proportions of the 3 products should show a binomial distribution $\left(\mathrm{N}_{2}=p^{2}, \mathrm{NO}=2 p q, \mathrm{O}_{2}=q^{2}\right)$, and account for the observed square root relationship of $\mathrm{N}_{2} \mathrm{O}_{2}$ with NO. This relationship was used to determine the excess amu 30 in the water samples. The excess amu 30 was converted to excess ${ }^{30} \mathrm{~N}_{2}$ concentration by comparing values with those of standard water. The results of a sediment incubation experiment designed to calibrate the MIMS signal showed that the sensitivities for the 3 forms of $\mathrm{N}_{2}$ gases are similar (An et al. 2001).
Concentration and at. \% ${ }^{15} \mathrm{~N}$ for $\mathrm{NH}_{4}{ }^{+}$were determined in water samples by high performance liquid chromatography (HPLC; Gardner et al. 1995). This cation exchange method quantifies the at. $\%{ }^{15} \mathrm{~N}$ of $\mathrm{NH}_{4}{ }^{+}$by measuring the shift in retention time of $\mathrm{NH}_{4}{ }^{+}$, relative to an internal standard, caused by the presence of ${ }^{15} \mathrm{NH}_{4}{ }^{+}$in the water sample. Concentration of total $\mathrm{NH}_{4}{ }^{+}$is quantified by comparing the size of the sample $\mathrm{NH}_{4}{ }^{+}$peak to that of the internal standard. This procedure is convenient to measure $\mathrm{NH}_{4}{ }^{+}$concentration and isotope ratio in water. The sample filtrate is injected directly into the HPLC system without the need to isolate the $\mathrm{NH}_{4}{ }^{+}$from the water and convert it to $\mathrm{N}_{2}$ gas before analysis as is required for mass spectrometry. Sediment flux was calculated based on the concentration difference between feed water and outflow water, flow rate, and cross-sectional area (Lavrentyev et al. 2000).

\section{RESULTS}

The dim light condition did not cause significant light effects so data from the 2 treatments (dark and dim light incubation) were combined. Light effects were also not observed during an in situ sediment core incubation experiment using light-dark benthic chambers in the study area (An \& Gardner 2000). However, light effects may have been underestimated in Laguna Madre where the light intensity was higher than in Baffin Bay. Sediment oxygen demand (SOD) was higher in August $1999\left(964 \pm 104 \mu \mathrm{mol} \mathrm{m}{ }^{-2} \mathrm{~h}^{-1}\right)$ than December 1999 (546 $\pm 33 \mu \mathrm{mol} \mathrm{m}^{-2} \mathrm{~h}^{-1}$; Fig. 3). Laguna Madre had a higher SOD (1069 \pm 68 and $621 \pm 13 \mu \mathrm{mol}$ $\mathrm{m}^{-2} \mathrm{~h}^{-1}$ in August and December 1999, respectively) than Baffin Bay $\left(858 \pm 78\right.$ and $489 \pm 15 \mu \mathrm{mol} \mathrm{m}{ }^{-2} \mathrm{~h}^{-1}$ in August and December 1999, respectively). SOD tended to increase after the ${ }^{15} \mathrm{NO}_{3}{ }^{-}$addition, but the difference was not significant for most stations (Fig. 3; $t$-test $\mathrm{p}>0.05)$. In August 1999, SOD at Stn B24 decreased from $1154 \pm 109 \mu \mathrm{mol} \mathrm{m} \mathrm{m}^{-2} \mathrm{~h}^{-1}$ before the ${ }^{15} \mathrm{NO}_{3}{ }^{-}$addition to $432 \pm 52 \mu \mathrm{mol} \mathrm{m}{ }^{-2} \mathrm{~h}^{-1}$ after the ${ }^{15} \mathrm{NO}_{3}{ }^{-}$addition. In December 1999, fluxes were monitored for $3 \mathrm{~d}$ in Laguna Madre (Fig. 3d) and for $6 \mathrm{~d}$ in Baffin Bay (Fig. 3c). SOD increased significantly in Baffin Bay Stns B6 and B24 on Day 6 (4 d after the ${ }^{15} \mathrm{NO}_{3}{ }^{-}$addition) relative to Day 3 (1 d after the addition; Fig. 3c; t-test $\mathrm{p}<0.05)$. In Laguna Madre, SOD was not significantly different on Day 2 (1 d after addition) from Day 3 (Fig. $3 d_{\text {; }} t$-test $\mathrm{p}>0.05$ ).

Figs. 4 \& 5 show the heavy $\mathrm{N}_{2}$ gas $\left({ }^{29+30} \mathrm{~N}_{2}\right)$ flux produced during ${ }^{15} \mathrm{NO}_{3}{ }^{-}$-based denitrification and ${ }^{15} \mathrm{NH}_{4}{ }^{+}$ flux produced from ${ }^{15} \mathrm{NO}_{3}^{-}$via DNRA, respectively. As expected, neither process was measurable before the ${ }^{15} \mathrm{NO}_{3}{ }^{-}$addition. After the ${ }^{15} \mathrm{NO}_{3}{ }^{-}$addition, average 
(a) Baffin bay (Aug-99)

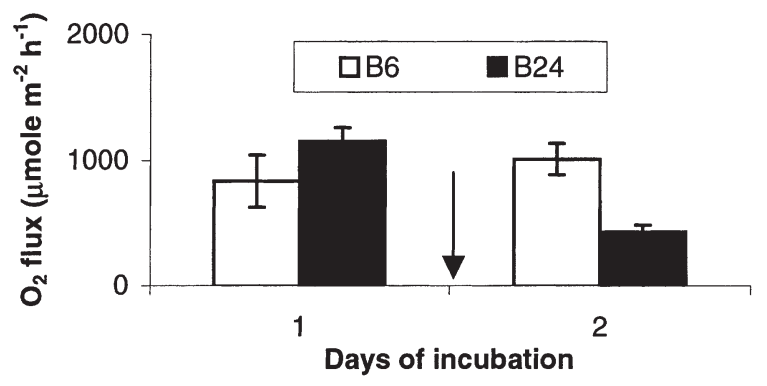

(c) Baffin bay (Dec-99)

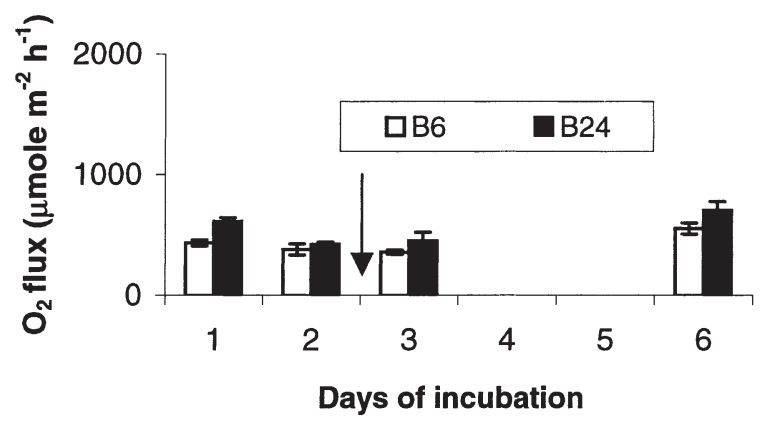

(b) Laguna Madre (Aug-99)

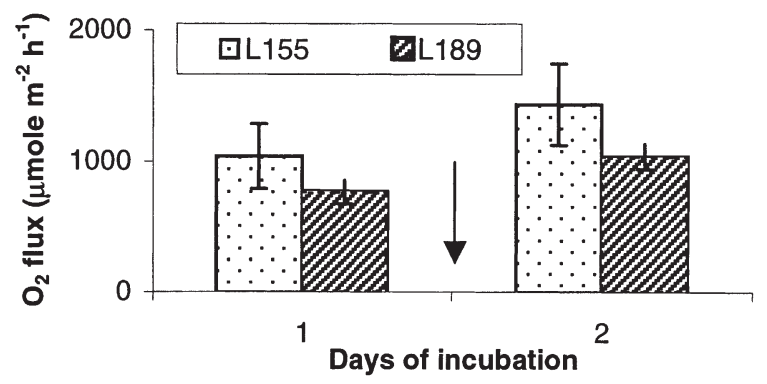

(d) Laguna Madre (Dec-99)

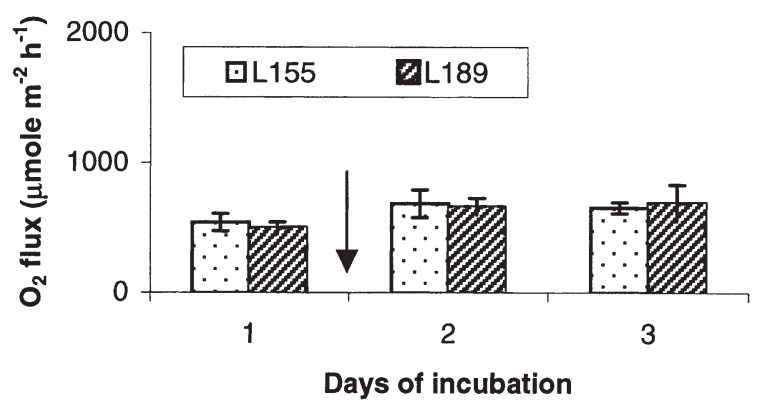

Fig. 3. Sediment oxygen demand $\left(\mu \mathrm{mol} \mathrm{m} \mathrm{m}^{-2} \mathrm{~h}^{-1}\right)$ before and after ${ }^{15} \mathrm{NO}_{3}{ }^{-}$addition. Arrows show the time of addition. Bars represent average flux and lines represent $\pm 1 \mathrm{SE}$ among 4 sediment cores

(a) Baffin bay (Aug-99)

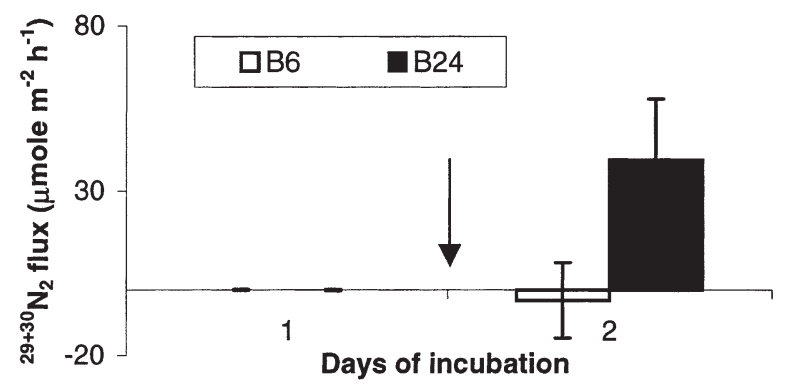

(c) Baffin bay (Dec-99)

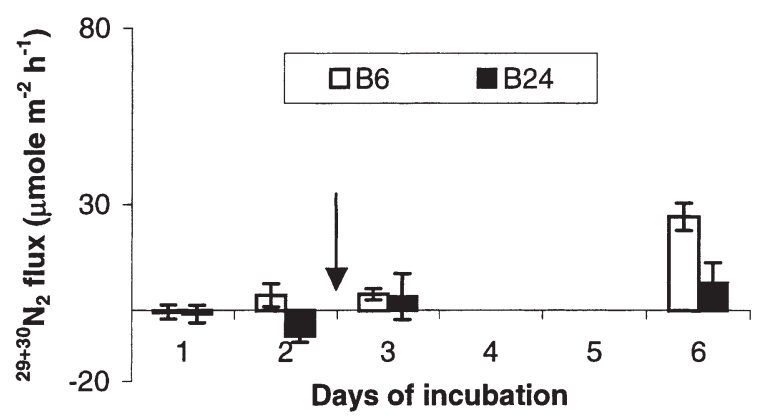

(b) Laguna Madre (Aug-99)

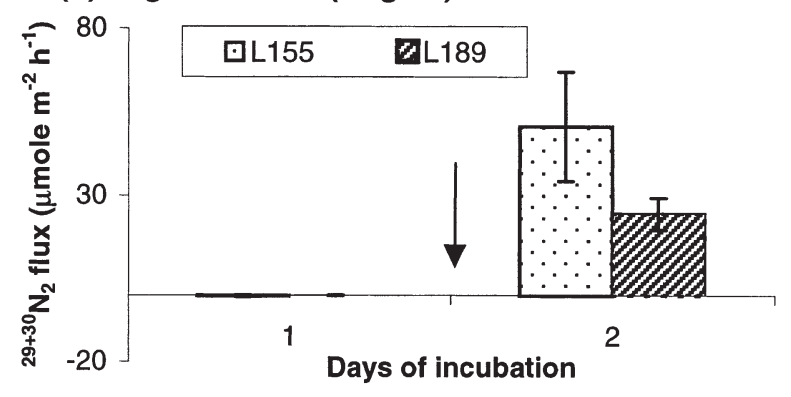

(d) Laguna Madre (Dec-99)

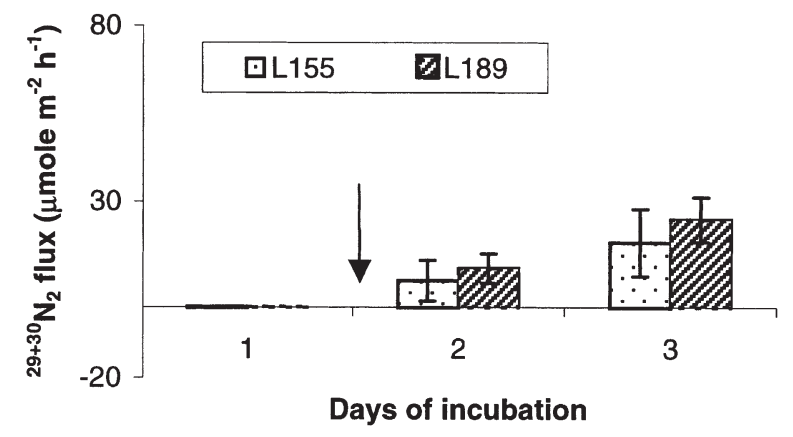

Fig. 4. Denitrification rate of ${ }^{15} \mathrm{NO}_{3}{ }^{-}\left({ }^{29} \mathrm{~N}_{2}\right.$ plus ${ }^{30} \mathrm{~N}_{2}$ production) before and after ${ }^{15} \mathrm{NO}_{3}{ }^{-}$addition. Arrows show the time of addition. Bars represent average and lines represent $\pm 1 \mathrm{SE}$ among 4 sediment cores 
(a) Baffin Bay (Aug-99)

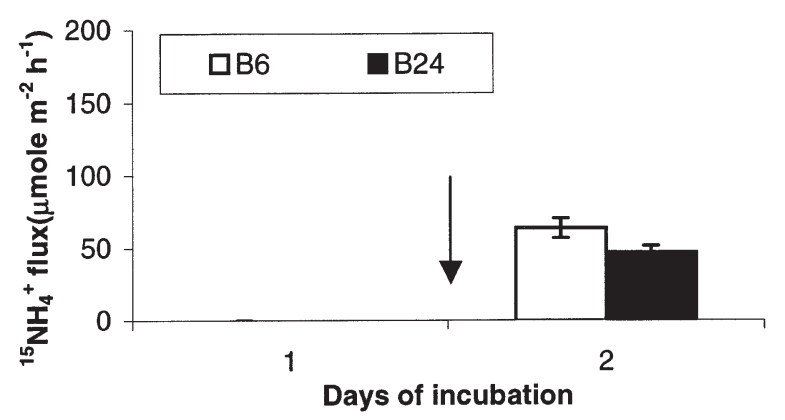

(c) Baffin Bay (Dec-99)

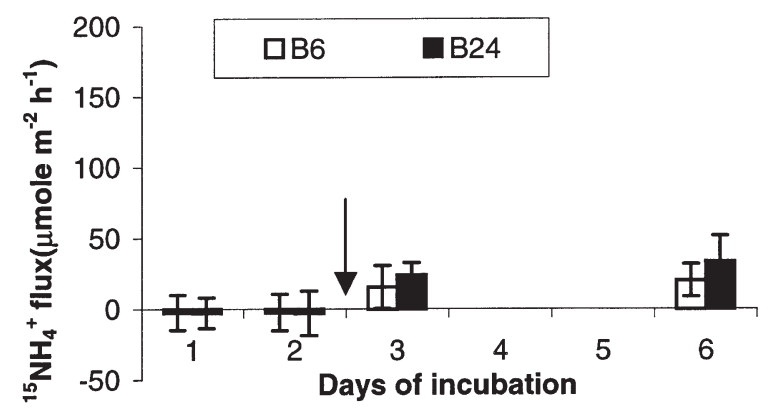

(b) Laguna Madre (Aug-99)

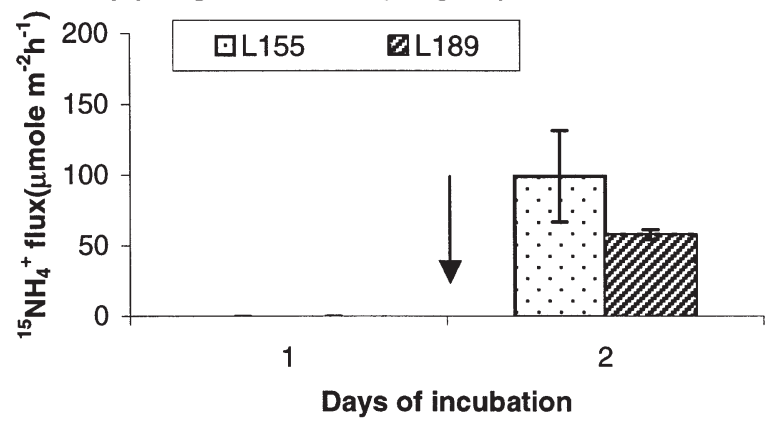

(d) Laguna Madre (Dec-99)

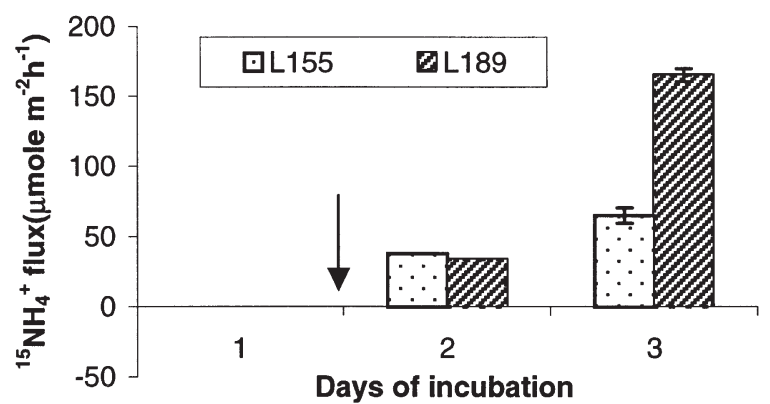

Fig. 5. Heavy ammonium $\left({ }^{15} \mathrm{NH}_{4}{ }^{+}\right)$flux before and after ${ }^{15} \mathrm{NO}_{3}{ }^{-}$addition. Arrows show the time of addition. Bars represent average and lines represent $\pm 1 \mathrm{SE}$ among 4 sediment cores

Table 2. Nitrogen gas $\left({ }^{28} \mathrm{~N}_{2}\right.$ and ${ }^{29+30} \mathrm{~N}_{2}$ ), $\mathrm{NO}_{3}{ }^{-}$and ${ }^{15} \mathrm{NH}_{4}{ }^{+}$flux ( $\mu$ mole -N equivalent $\mathrm{m}^{-2} \mathrm{~h}^{-1}$ ) during sediment incubation experiments in August and December 1999. Average flux (standard error) among replicate cores ( $\mathrm{n}=16$ to $\mathrm{N} 32$ ) were presented before and after the ${ }^{15} \mathrm{NO}_{3}{ }^{-}$addition. Negative flux denotes a flux into the sediment. Percent of recovery for ${ }^{29+30} \mathrm{~N}_{2}$ and ${ }^{15} \mathrm{NH}_{4}{ }^{+}$was calculated assuming that all the $\mathrm{NO}_{3}{ }^{-}$flux consisted of ${ }^{15} \mathrm{NO}_{3}{ }^{-}$

\begin{tabular}{|c|c|c|c|c|c|c|c|}
\hline & ${ }^{28} \mathrm{~N}_{2}$ flux & $\mathrm{NO}_{3}^{-}$flux & $\overline{\text { Flux }}^{2}$ & $\begin{array}{l}{ }^{29+30} \mathrm{~N}_{2} \\
\% \text { of } \mathrm{NO}_{3}^{-} \text {flux }\end{array}$ & \multicolumn{2}{|c|}{$\begin{array}{l}{ }^{15} \mathrm{NH}_{4}{ }^{+}- \\
\text {Flux }\end{array} \%$ of $\mathrm{NO}_{3}^{-}$flux } & $\begin{array}{c}\%{ }^{15} \mathrm{NO}_{3}{ }^{-} \text {recovery } \\
\text { as } \mathrm{N}_{2}+\mathrm{NH}_{4}{ }^{+}\end{array}$ \\
\hline \multicolumn{8}{|l|}{ August } \\
\hline \multicolumn{8}{|c|}{ Baffin Bay } \\
\hline Before & $67.8(15.8)$ & $0.74(1.3)$ & $0(0)$ & & $0(0)$ & & \\
\hline After & $47.5(6.5)$ & $-370(103)$ & $18.2(21.3)$ & 4.9 & $55.4(8.3)$ & 15.0 & 19.9 \\
\hline \multicolumn{8}{|c|}{ Laguna Madre } \\
\hline Before & $41.3(14.3)$ & 0.23 & $-0.12(0.04)$ & & 0 & & \\
\hline After & $35.3(20.3)$ & $-128(79)$ & 37.6 (13) & 29.4 & $78.6(20)$ & 61.4 & 90.8 \\
\hline \multicolumn{8}{|l|}{ December } \\
\hline \multicolumn{8}{|c|}{ Baffin Bay } \\
\hline Before & $-2.3(9.3)$ & $1.2(0.3)$ & $-1.05(2.7)$ & & $-2.5(0.37)$ & & \\
\hline After & $3.1(10.5)$ & $-146(4.3)$ & $10.7(5.4)$ & 7.3 & $23.3(3.8)$ & 16.0 & 23.3 \\
\hline \multicolumn{8}{|c|}{ Laguna Madre } \\
\hline Before & $-19.9(5.2)$ & $0.13(0.04)$ & $0.34(9.2)$ & & $-0.7(0.9)$ & & \\
\hline After & $-9.0(8.8)$ & $-101.7(33)$ & 15.5 (9.9) & 15.2 & 76.1 (18) & 74.8 & 90.1 \\
\hline
\end{tabular}

fluxes were 10.7 to 37.6 and 23.3 -to $76.8 \mu \mathrm{mol} \mathrm{m}{ }^{-2} \mathrm{~h}^{-1}$ for ${ }^{29+30} \mathrm{~N}_{2}$ and ${ }^{15} \mathrm{NH}_{4}{ }^{+}$, respectively (Table 2). Production of ${ }^{15} \mathrm{~N}$ products sometimes increased with time after ${ }^{15} \mathrm{NO}_{3}{ }^{-}$addition (Figs. 4 \& 5c,d). At Stn B6, $\mathrm{N}_{2}$ gas $\left({ }^{29+30} \mathrm{~N}_{2}\right)$ flux increased significantly on Day 6 versus Day 3 (Fig. 4c). At Stns L155 and L189, ${ }^{15} \mathrm{NH}_{4}{ }^{+}$flux increased significantly on Day 3 versus Day 2 of the incubation (Fig. 5d). Except for these incidents, the increases in fluxes over time were not significant (Figs. 4 \& 5c,d).

Flux changes in the different forms of $\mathrm{N}_{2}$ gas and $\mathrm{NO}_{3}{ }^{-}$and $\mathrm{NH}_{4}{ }^{+}$before and after the ${ }^{15} \mathrm{NO}_{3}{ }^{-}$addition are 
presented in Table 2 . The denitrification rate based on the ${ }^{14} \mathrm{NO}_{3}{ }^{-}\left({ }^{28} \mathrm{~N}_{2}\right.$ production; before ${ }^{15} \mathrm{NO}_{3}{ }^{-}$addition) was higher in August than in December 1999. Negative ${ }^{28} \mathrm{~N}_{2}$ flux (flux into the sediment) was observed in December 1999, suggesting $\mathrm{N}$ fixation. However, the rate was significantly different from zero only at Laguna Madre stations ( $<$ 0.05). The Baffin Bay stations had higher ${ }^{28} \mathrm{~N}_{2}$ production than Laguna Madre in August and December 1999, but the difference was not significant.

In August 1999, 'total' denitrification activity $\left({ }^{28} \mathrm{~N}_{2}\right.$ plus ${ }^{29+30} \mathrm{~N}_{2}$ ) did not increase significantly after the ${ }^{15} \mathrm{NO}_{3}{ }^{-}$ addition ( $p>0.05)$. Total denitrification rates increased after the addition in December 99, but the amounts were small (16 and $26 \mu \mathrm{mol} \mathrm{m}{ }^{-2} \mathrm{~h}^{-1}$ in Baffin Bay and Laguna Madre, respectively) and the increase was not significant in Baffin Bay $(p>0.05) .{ }^{15} \mathrm{NH}_{4}{ }^{+}$fluxes after the addition ranged from 23 to $79 \mu \mathrm{mol} \mathrm{m}{ }^{-2} \mathrm{~h}^{-1}$ (Table 2). Laguna Madre had a higher ${ }^{15} \mathrm{NH}_{4}{ }^{+}$flux than Baffin Bay. A seasonal trend was not obvious in Laguna Madre while the ${ }^{15} \mathrm{NH}_{4}{ }^{+}$flux in Baffin Bay was higher in August 1999 compared to December 1999. In December 1999, a small negative ${ }^{15} \mathrm{NH}_{4}{ }^{+}$flux was observed before the addition, probably due to analytical variability of the HPLC system (Gardner et al. 1995).

Before the addition, a small $\mathrm{NO}_{3}{ }^{-}$flux out of the sediments was observed at all stations during both seasons. After the addition, $\mathrm{NO}_{3}{ }^{-}$fluxes into the sediment were high (up to $370 \mu \mathrm{mol} \mathrm{m}{ }^{-2} \mathrm{~h}^{-1}$ ). Baffin Bay sediments consumed more $\mathrm{NO}_{3}^{-}$(higher negative $\mathrm{NO}_{3}{ }^{-}$ flux) than Laguna Madre sediments after the addition, but the difference between the 2 sites was smaller in December 1999. Since $\mathrm{NO}_{3}{ }^{-}$fluxes were small before the addition, all $\mathrm{NO}_{3}{ }^{-}$flux after the addition was assumed to be ${ }^{15} \mathrm{NO}_{3}{ }^{-}$for comparison with ${ }^{29+30} \mathrm{~N}_{2}$ and ${ }^{15} \mathrm{NH}_{4}{ }^{+}$fluxes. Denitrification consumed 5 to $29 \%$ of the added ${ }^{15} \mathrm{NO}_{3}{ }^{-}$while DNRA accounted for 15 to $75 \%$ of the added ${ }^{15} \mathrm{NO}_{3}^{-}$(Table 2). Both ${ }^{29+30} \mathrm{~N}_{2}$ and ${ }^{15} \mathrm{NH}_{4}{ }^{+}$fluxes were smaller in Baffin Bay than Laguna Madre, whereas $\mathrm{NO}_{3}{ }^{-}$flux was higher in Baffin Bay. As a result, the percentage recovery of added ${ }^{15} \mathrm{NO}_{3}{ }^{-}$was higher in Laguna Madre than Baffin Bay. The recovery of ${ }^{15} \mathrm{NO}_{3}{ }^{-}$as ${ }^{29+30} \mathrm{~N}_{2}$ and ${ }^{15} \mathrm{NH}_{4}{ }^{+}$did not show seasonal differences. For example, ${ }^{15} \mathrm{NH}_{4}{ }^{+}$flux remained almost the same in December as in August 1999. The total recovery of added ${ }^{15} \mathrm{NO}_{3}{ }^{-}$as ${ }^{29+30} \mathrm{~N}_{2}$ and ${ }^{15} \mathrm{NH}_{4}{ }^{+}$ranged from 20 to $91 \%$, but seasonal differences were not noticeable.

\section{DISCUSSION}

Denitrification rates in Baffin Bay (0 to $68 \mu \mathrm{mol} \mathrm{m} \mathrm{m}^{-2}$ $\mathrm{h}^{-1}$ ) and Laguna Madre (0 to $\left.41 \mu \mathrm{mol} \mathrm{m}{ }^{-2} \mathrm{~h}^{-1}\right)$ are in the range of those reported for other coastal marine envi- ronments (Seitzinger 1988, Herbert 1999) but lower than those for other Texas estuaries, such as Galveston Bay $\left(\sim 170 \mu \mathrm{mol} \mathrm{m} \mathrm{m}^{-2} \mathrm{~h}^{-1}\right.$, using direct $\mathrm{N}_{2}$ flux method; An \& Joye 2001). Denitrification rates measured in Galveston Bay with the $\mathrm{N}_{2}$ flux method after gas purging ( 0 to $47 \mu \mathrm{mol} \mathrm{m}{ }^{-2} \mathrm{~h}^{-1}$; Zimmerman \& Benner 1994) were comparable to our measurements although the gas purging denitrification method is problematic because of extended incubation times required to remove atmospheric $\mathrm{N}_{2}$ (see reviews in An \& Joye 1997, Cornwell et al. 1999). Results from other denitrification measurements using the gas purging $\mathrm{N}_{2}$ flux method in Texas estuaries are also similar to the rates of this study (4 to 71 and 4.6 to $35 \mu \mathrm{mol} \mathrm{m} \mathrm{m}^{-2} \mathrm{~h}^{-1}$ for Nueces and Guadalupe estuaries, respectively; Yoon \& Benner 1992).

In April 1999, denitrification rates were measured in Laguna Madre and Baffin Bay using the same experimental setup as in the current study without ${ }^{15} \mathrm{NO}_{3}$ enrichment (An \& Gardner 2000). Mean denitrification rates observed in April $1999\left(\sim 130 \mu \mathrm{mol} \mathrm{m}{ }^{-2} \mathrm{~h}^{-1}\right.$; An \& Gardner 2000) were higher than in August 1999 (41 to $77 \mu \mathrm{mol} \mathrm{m} \mathrm{m}^{-2} \mathrm{~h}^{-1}$; current study) despite the lower temperature. SOD was also higher in spring $(\sim 1500 \mu \mathrm{mol}$ $\mathrm{m}^{-2} \mathrm{~h}^{-1}$; An \& Gardner 2000) than in August 1999 (964 $\mu \mathrm{mol} \mathrm{m} \mathrm{m}^{-2} \mathrm{~h}^{-1}$; Current study). Low SOD in August 1999 may have resulted from organic matter limitation. Water column chl a concentration was highest in April 1999 and decreased in August and December 1999 in Laguna Madre/Baffin Bay (T. Villareal unpubl. data), suggesting a tight benthic-pelagic coupling. Low concentrations of available organic carbon would limit heterotrophic activity even under favorable temperatures. Since denitrification is a heterotrophic process, low organic matter availability could also limit denitrification rates (Koike \& Sørensen 1988, Cornwell et al. 1999). Another explanation for the low summertime denitrification rates could be sulfide inhibition (Gould \& McCready 1982, Jensen \& Cox 1992, Joye \& Hollibaugh 1995). Anoxic regeneration would increase as oxygen is consumed. In a saline estuary like Laguna Madre/Baffin Bay (salinity during this study $=25$ to $38 \mathrm{ppt}$ ), sulfate reduction is a major anoxic process and sulfide (the product of sulfate reduction) concentrations in porewater may increase under low oxygen conditions (Morse et al. 1992). Sulfide is toxic to many sediment bacterial processes including nitrification and denitrification (Gould \& McCready 1982, Jensen \& Cox 1992, Joye \& Hollibaugh 1995). Due to the shallow water depth, the water column was well mixed, even in August 1999 (Table 1), but oxygen penetration-depth of the sediment may have decreased during summer at times when conditions were stable. Although porewater sulfide concentrations were not measured in the current study area, high sulfate reduction activity near 
the sediment water interface (43 to $112 \mathrm{mmol} \mathrm{l}^{-1} \mathrm{yr}^{-1}$ in June 1988; Morse et al. 1992) and high porewater sulfide concentrations (up to $5500 \mu \mathrm{M}$ in June 1988, Morse et al. 1992; 102 to $160 \mu \mathrm{M}$ in July 1996, Lee \& Dunton 2000) occur in this region. It is also possible that salinity-induced inhibition of denitrifying activity by physiological effects other than sulfide inhibition could explain the low denitrification activity in saline estuaries like Baffin Bay and Laguna Madre (Rysgaard et al. 1999). Additionally, ${ }^{15} \mathrm{NO}_{3}{ }^{-}$may have converted to ${ }^{15} \mathrm{~N}_{2} \mathrm{O}$ by incomplete denitrification in a high sulfide environment (Brundet \& Garcia-Gil 1996). Although the production of ${ }^{15} \mathrm{~N}_{2} \mathrm{O}$ was not quantitatively measured, ${ }^{15} \mathrm{~N}_{2} \mathrm{O}$ signals (amu 46) were within background levels, suggesting that large amounts of ${ }^{15} \mathrm{~N}_{2} \mathrm{O}$ were not produced during the measurement.

In winter, denitrification rates were not significantly different from zero, and $\mathrm{N}_{2}$ flux into the sediment due to $\mathrm{N}_{2}$ fixation was visible in Laguna Madre. $\mathrm{N}_{2}$ flux in Laguna Madre $\left(20 \mu \mathrm{mol} \mathrm{m} \mathrm{m}^{-2} \mathrm{~h}^{-1}\right)$ may provide a conservative estimate of net $\mathrm{N}_{2}$ fixation in this area because our incubation was done under dark or low light conditions (Joye \& Paerl 1994, An et al. 2001). The measured rate is at the low end of the range reported for other seagrass beds. Typically, seagrass beds have higher $\mathrm{N}_{2}$ fixation rates ( 1 to $250 \mu \mathrm{mol} \mathrm{m}^{-2} \mathrm{~h}^{-1}$ ) than uncolonized areas (0.02 to $5 \mu \mathrm{mol} \mathrm{m}{ }^{-2} \mathrm{~h}^{-1}$; Herbert 1999).

Total denitrification rates $\left({ }^{28} \mathrm{~N}_{2}+{ }^{29+30} \mathrm{~N}_{2}\right)$ were not enhanced significantly by ${ }^{15} \mathrm{NO}_{3}{ }^{-}$additions. This result was surprising because in many estuaries denitrification is limited by $\mathrm{NO}_{3}{ }^{-}$availability (Koike \& Sørensen 1988, Cornwell et al. 1999). Instead, a portion of the added ${ }^{15} \mathrm{NO}_{3}{ }^{-}$was converted to ${ }^{15} \mathrm{NH}_{4}{ }^{+}$. The ${ }^{15} \mathrm{NH}_{4}{ }^{+}$ production rate ranged from about 20 to $80 \mu \mathrm{mol} \mathrm{m}{ }^{-2}$ $\mathrm{h}^{-1}$ after the ${ }^{15} \mathrm{NO}_{3}{ }^{-}$addition. Although the ${ }^{15} \mathrm{NO}_{3}{ }^{-}$ enrichment level varied $(\sim 15$ to $30 \mu \mathrm{M}$ and $\sim 100 \mu \mathrm{M}$ in Koike \& Hattori [1978] and this study, respectively) and the experimental setup was different, ${ }^{15} \mathrm{NH}_{4}{ }^{+}$production rates were comparable to those measured in Koike \& Hattori $\left(1978 ; 5\right.$ to $228 \mu \mathrm{mol} \mathrm{m} \mathrm{m}^{-2} \mathrm{~h}^{-1}$, assuming 0 to $3 \mathrm{~cm}$ depth integration and $2.3 \mathrm{~g} \mathrm{~cm}^{-3}$ bulk sediment density). Higher production rates (800 to $3200 \mu \mathrm{mol}$ $\mathrm{m}^{-2} \mathrm{~h}^{-1}$ ) were observed with a high ${ }^{15} \mathrm{NO}_{3}{ }^{-}$enrichment ( $700 \mu \mathrm{m}$, assuming 0 to $4 \mathrm{~cm}$ depth integration; Jørgensen 1989). Our rates were much lower than those from a sediment slurry incubation $\left(\sim 2300 \mu \mathrm{mol} \mathrm{m}^{-2} \mathrm{~h}^{-1}\right.$; assuming 0 to $12 \mathrm{~cm}$ depth integration; Sørensen 1978) with a similar ${ }^{15} \mathrm{NO}_{3}{ }^{-}$enrichment $(\sim 100 \mu \mathrm{M})$. Reducing conditions favor DNRA over denitrification, and slurry experiments tend to have higher DNRA rates compared to intact core experiments (Kasper 1983). In our study, DNRA rates were higher than denitrification rates even though intact cores were used for incubation and $\mathrm{O}_{2}$ concentration in the water column was maintained at more than $80 \%$ of saturation. Thus, it seems unlikely that this high DNRA partitioning over denitrification resulted from reduced conditions in the sediments as suggested by Kasper (1983). We do not believe that the high partitioning of $\mathrm{NO}_{3}{ }^{-}$to DNRA was a result of ${ }^{15} \mathrm{NO}_{3}{ }^{-}$enrichment. $\mathrm{NO}_{3}{ }^{-}$enrichment should not only stimulate denitrification and DNRA but can be expected to favor denitrification over DNRA (Sørensen 1987). Additionally, since DNRA bacteria have a higher $K_{\mathrm{m}}$ (half saturation concentration, 100 to $500 \mu \mathrm{M}$ $\mathrm{NO}_{3}{ }^{-}$; Jørgensen 1989) than denitrifiers (5 to $10 \mu \mathrm{M}$ $\mathrm{NO}_{3}^{-}$; Jørgensen 1989), the enrichment level in our study $(\sim 100 \mu \mathrm{M})$ should firstly favor denitrification rather than DNRA if denitrification was limited by $\mathrm{NO}_{3}{ }^{-}$availability.

Low denitrification and high DNRA were observed during summer in a French coastal lagoon (Rysgaard et al. 1996). Sulfate reduction was high and low denitrification rates were attributed to inhibited nitrification. High DNRA was attributed to the presence of sulfate reducing bacteria, which have DNRA capacity as a secondary metabolism (Rysgaard et al. 1996). This observation agrees with those of King \& Nedwell (1985) and Jørgensen (1989). DNRA may be favored in environments where $\mathrm{NO}_{3}{ }^{-}$availability is variable because DNRA bacteria have constitutive enzymes (Jørgensen 1989).

Chemolithoautotrophic bacteria that use reduced sulfur compounds as an electron donor and reduce $\mathrm{NO}_{3}{ }^{-}$to $\mathrm{NH}_{4}{ }^{+}$have been reported (Schedel \& Truper 1980), but the ecological significance of the process is not known (Sørensen 1987). $\mathrm{NH}_{4}^{+}$production rates coincided with $\mathrm{NO}_{3}{ }^{-}$and $\mathrm{H}_{2} \mathrm{~S}$ depletion rates in sediment slurry experiments enriched with $\mathrm{NO}_{3}{ }^{-}$and different forms of sulfur compounds (Brundet \& GarciaGil 1996). Whereas denitrification was incomplete (the final product was $\mathrm{N}_{2} \mathrm{O}$ instead of $\mathrm{N}_{2}$ ), DNRA occurred in the presence of high sulfide concentrations. In contrast, denitrification was the major $\mathrm{NO}_{3}{ }^{-}$sink when sulfide concentrations were low (Brundet \& Garcia-Gil 1996). Abundant populations of $\mathrm{NO}_{3}{ }^{-}$-storing sulfur bacteria of the genera Thioploca, Beggiatoa and Thiomargarita have been reported in sediments of coastal upwelling regions (Schulz et al. 1999, Graco et al. 2001). A chemolithotrophic coupling of $\mathrm{NO}_{3}{ }^{-}$and sulfide through $\mathrm{NO}_{3}{ }^{-}$-storing sulfur bacteria may be a widespread feature of coastal sediments (Schulz et al. 1999).

Along with the high sulfide concentrations that occur in this region (Lee \& Dunton in press), our data support the idea that sulfide could influence DNRA at both of our sampling sites. Being a negative estuary where evaporation exceeds precipitation, salinity in Laguna Madre/Baffin Bay is high and sulfate reduction may be a major organic-matter degradation process. Higher DNRA observed in Laguna Madre versus Baffin Bay 


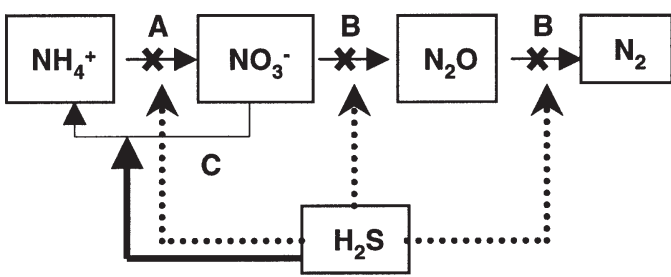

A: Nitrification

B: Denitrification

C: Dissimilatory nitrate reduction to ammonium

Fig. 6. Proposed relationship between sulfide and nitrogen transformations. Solid arrows represent a positive effects and broken arrows represent a negative effects. Modified from Brunet \& Garcia-Gil (1996)

(Table 2) could result from high sulfide reduction activity fueled by seagrass detritus (Rysgaard 1996, Eldridge \& Morse et al. 2000, Graco et al. 2001). Fig. 6 shows how sulfide may influence $\mathrm{N}$ transformations in this system. High sulfide concentrations may inhibit nitrification and keep $\mathrm{NO}_{3}^{-}$availability low. Since denitrification is inhibited by sulfide, any $\mathrm{NO}_{3}{ }^{-}$that is present will be available for DNRA rather than denitrification. Inhibition of denitrification can explain the enhanced DNRA that we observed, even though the $K_{\mathrm{m}}$ for DNRA bacteria is higher than for denitrifiers, and ${ }^{15} \mathrm{NO}_{3}{ }^{-}$enrichment was low. Although high sulfide concentrations inhibit nitrification and denitrification, sulfide may fuel DNRA by providing an electron donor. High SOD, high DNRA and low denitrification rates in Laguna Madre compared to Baffin Bay support this hypothesis.

The recovery of ${ }^{15} \mathrm{NO}_{3}{ }^{-}$as ${ }^{15} \mathrm{NH}_{4}{ }^{+}$and ${ }^{29+30} \mathrm{~N}_{2}$ was higher in Laguna Madre than Baffin Bay (Table 2). ${ }^{15} \mathrm{NO}_{3}{ }^{-}$flux into the sediment was higher in Baffin Bay while ${ }^{15} \mathrm{NH}_{4}{ }^{+}$and ${ }^{29+30} \mathrm{~N}_{2}$ flux was lower than in Laguna Madre, which caused low ${ }^{15} \mathrm{NO}_{3}{ }^{-}$recovery in Baffin Bay. The ${ }^{15} \mathrm{NH}_{4}{ }^{+}$flux difference was more distinctive than the ${ }^{29+30} \mathrm{~N}_{2}$ flux. Possible explanations are differences in sediment types between the 2 sites and/or the presence of seagrasses in Laguna Madre but not in Baffin Bay. The abundance and community structure of microbes in the seagrass bed may be different than those regions without seagrass. For example, bacteria responsible for ${ }^{15} \mathrm{NH}_{4}{ }^{+}$production in Laguna Madre may be sulfate reducers that have $\mathrm{NO}_{3}{ }^{-}$reduction capability as a second metabolism (Rysgaard et al. 1996).

The ${ }^{15} \mathrm{~N}$ content in organic matter was not measured in our study but it is reasonable to speculate that a loss to organic $\mathrm{N}$ production could account for some of the lost ${ }^{15} \mathrm{NO}_{3}{ }^{-}$, even though the proportion may be small (Jørgensen 1989; 2 to $4 \%$ ). Our average recovery of $56 \%$ was similar to that in Norsminde Fjord, Denmark (Jørgensen 1989). However, the proportion of DNRA (recovered as ${ }^{15} \mathrm{NH}_{4}{ }^{+}$) was higher $(42 \%$ ) than values reported by Jørgensen (1989; $22 \%$ ). Recovery via denitrification in our study was $14 \%$, which is lower than the Jørgensen $(24 \%$; 1989) or Kasper values (70 to $95 \%$; 1983).

Sulfide-inhibited denitrification and sulfide-induced DNRA would contribute to the preservation of $\mathrm{N}$ in Laguna Madre/Baffin Bay. Preserved N may sustain biota in this region when other nutrient inputs are absent. It also may explain apparent phosphate limitation of primary production observed at times in the region (Dr. J. Cotner, University of Minnesota, pers. comm.). High DNRA potential in this region suggests that the dominant form of inorganic $\mathrm{N}$ available to phytoplankton is $\mathrm{NH}_{4}{ }^{+}$rather than $\mathrm{NO}_{3}{ }^{-}$. The Texas brown tide organism, Aureomonas lagunensis, which can use $\mathrm{NH}_{4}{ }^{+}$or $\mathrm{NO}_{2}{ }^{-}$, but cannot use $\mathrm{NO}_{3}{ }^{-}$as a nitrogen source, could outcompete other algae in this $\mathrm{NH}_{4}{ }^{+}$ replete environment. It is reasonable to suggest that the persistency of the Brown Tide algal bloom in this area may have been enhanced by DNRA activity.

Acknowledgements. This study was supported by the Texas Water Development Board (Contract \# 99-483-278; David Brock, Project officer) and by the Nancy Lee and Perry Bass Regents Chair in Marine Science (held by W.S.G.). We thank Mark McCarthy and Rick Kalke for technical assistance, Todd Kana for assistance with the MIMS system and Jay Brandes for constructive discussions.

\section{LITERATURE CITED}

An S, Gardner WS (2000) Nitrogen cycling in Laguna Madre and Baffin Bay. Final report to Texas Water Development Board, No. 44

An S, Joye SB (1997) An improved chromatographic method to measure nitrogen, oxygen, argon and methane in gas or liquid samples. Mar Chem 59:63-70

An S, Joye SB (2001) Enhancement of coupled nitrificationdenitrification by benthic photosynthesis in shallow estuarine sediments. Limnol Oceanogr 46(1):62-74

An S, Gardner WS, Kana TM (2001) Simultaneous measurement of denitrification and nitrogen fixation using isotope pairing with membrane inlet mass spectrometer (MIMS) analysis. Appl Environ Microbiol 67(3):1171-1178

Binnerup SJ, Jensen, K, Revsbech NP, Jensen MH, Sørensen J (1992) Denitrification, dissimilatory reduction of nitrate to ammonium, and nitrification in a bioturbated estuarine sediment as measured with ${ }^{15} \mathrm{~N}$ and microsensor techniques. Appl Environ Microbiol 58(1):303-313

Bonin P, Omnes P, Chalamet A (1998) Simultaneous occurrence of denitrification and nitrate ammonification in sediments of the French Mediterranean coast. Hydrobiologia 389(1-3):169-182

Brundet RC, Garcia-Gil LJ (1996) Sulfide-induced dissimilatory nitrate reduction to ammonia in anaerobic freshwater sediments. FEMS Microbiol Ecol 21:131-138

Buskey EJ, Wysor B, Hyatt C (1998) The role of hypersalinity in the persistence of the Texas 'brown tide' in the Laguna Madre. J Plankton Res 20(8):1553-1565 
Cornwell JC, Kemp WM, Kana TM (1999) Denitrification in coastal ecosystems: methods, environmental controls and ecosystem level controls, a review. Aquat Ecol 33: 41-54

DeYoe HR, Suttle CA (1994) The inability of the Texas brown tide alga to use nitrate and the role of nitrogen in the initiation of a persistent bloom of this organism. J Phycol 30: 800-806

Eldridge PM, Morse JW (2000) A diagenetic model for sediment-seagrass interactions. Mar Chem 70:89-103

Gardner WS, Bootsma HA, Evans C, St. John PA (1995) Improved chromatographic analysis of ${ }^{15} \mathrm{~N}:{ }^{14} \mathrm{~N}$ ratios in ammonium or nitrate for isotope addition experiments. Mar Chem 48:271-382

Gould WD, McCready GL (1982) Denitrification in several soils: inhibition by sulfur anions. Can J Microbiol 28: 334-340

Graco M, Farias L, Molina V, Gutierrez D, Nielsen LP (2001) Massive developments of microbial mats following phytoplankton blooms in a naturally eutrophic bay: implications for nitrogen cycling. Limnol Oceanogr 46(4):821-832

Herbert RA (1999) Nitrogen cycling in coastal marine ecosystems. FEMS Microbiol Rev 23:563-590

Howarth RW, Marino R, Lane J, Cole JJ (1988) Nitrogen fixation in freshwater, estuarine and marine ecosystems. I. Rates and importance. Limnol Oceanogr 33:669-687

Jensen KM, Cox RP (1992) Effects of sulfide and low redox potential on the inhibition of nitrous oxide reduction by acetylene in Pseudomonas nautica. FEMS Microbiol Lett 96:13-18

Jensen KM, Jensen MH, Cox RP (1996) Membrane inlet mass spectrometric analysis of $\mathrm{N}$-isotope labeling for aquatic denitrification studies. FEMS Microbiol Ecol 20:101-109

Jørgensen KS (1989) Annual pattern of denitrification and nitrate ammonification in estuarine sediment. Appl Environ Microbiol 55:1841-1847

Joye SB, Hollibaugh JT (1995) Sulfide inhibition of nitrification influences nitrogen regeneration in sediments. Science 270:623-625

Joye SB, Paerl HW (1994) Nitrogen cycling in microbial mats: rates and patterns of denitrification and nitrogen fixation. Mar Biol 119(2):285-295

Kana TM, Darkangelo C, Hunt MD, Oldham JB, Bennett GE, Cornwell JC (1994) Membrane inlet mass spectrometer for rapid high-precision determination of $\mathrm{N}_{2}, \mathrm{O}_{2}$, and $\mathrm{Ar}$ in environmental water samples. Anal Chem 66(23): 4166-4170

Kasper HF (1983) Denitrification, nitrate reduction to ammonium and inorganic nitrogen pools in intertidal sediments. Mar Biol 74:133-139

King D, Nedwell DB (1985) The influence of nitrate concentration upon the end-products of nitrate dissimilation by bacteria in anaerobic salt marsh sediment. FEMS Microbiol Ecol 31(1):23-28

Knowles R (1990) Acetylene inhibitions technique: development, advantage, and potential problems. In: Revsbech NP, Sørensen J (eds) Denitrification in soils and sediment. FEMS Symposium, No. 56. Plenum Press, New York, p 1151-1166

Koike I, Hattori A (1978) Denitrification and ammonia formation in anaerobic coastal sediments. Appl Environ Microbiol 35(2):278-282

Koike I, Sørensen J (1988) Nitrate reduction and denitrification in marine sediments. In: Blackburn TH, Sørensen J

Editorial responsibility: Otto Kinne (Editor),

Oldendorf/Luhe, Germany (eds) Nitrogen cycling in coastal marine environments. Wiley-Liss, New York, p 251-283

Lavrentyev P, Gardner WS, Yang L (2000) Effects of the Zebra mussel on microbial composition and nitrogen dynamics at the sediment-water interface in Saginaw Bay, Lake Huron. Aquat Microb Ecol 21:187-194

Lee KS, Dunton KH (1999) Inorganic nitrogen acquisition in the seagrass Thalassia testudinum: development of a whole-plant nitrogen budget. Limnol Oceanogr 44(5): 1204-1215

Lee KS, Dunton KH (2000) Diurnal changes in pore water sulfide concentrations in the seagrass Thalassia testudinum beds: the effects of seagrasses on sulfide dynamics. J Exp Mar Biol Ecol 225(2):201-214

Lide DR (1992) CRC Handbook of chemistry and physics. CRC Press, London

Montagna PA, Kalke RD (1995) Ecology of infaunal Mollusca in South Texas estuaries. Am Malacol Bull 11(2):163-175

Morse JW, Cornwell JC, Arakaki T, Lin S, Huerta-Diaz M (1992) Iron sulfide and carbonate mineral diagenesis in Baffin Bay, Texas. J Sediment Petrol 62(4):671-680

Nielson LP (1992) Denitrification in sediment determined from nitrogen isotope pairing. FEMS Microbiol Ecol 86: $357-362$

Patrick O, Slawayk G, Garcia N, Bonin P (1996) Evidence of denitrification and nitrate ammonification in the river Rhone plum (northwestern Mediterranean Sea). Mar Ecol Prog Ser 141:275-281

Rysgaard S, Risgaard-Petersen N, Sloth NP (1996) Nitrification, denitrification, and nitrate ammonification in sediments of two coastal lagoons in southern France. Hydrobiologia 329(1-3):133-141

Rysgaard S, Thastum p, Dalsgaard T, Christensen PB, Sloth NP (1999) Effects of salinity on $\mathrm{NH}_{4}{ }^{+}$absorption, nitrification, and denitrification in Danish estuarine sediments. Estuaries 22(1):21-30

Schedel M, Truper H (1980) Anaerobic oxidation of thiosulfate and elemental sulfur in Thiobacillus denitrificans. Arch Microbiol 124:205-210

Schulz HN, Brinkhoff T, Ferdelman TG, Hernandez Marine M, Teske A, Jørgensen BB (1999) Dense population of a giant sulfur bacterium in Namibian shelf sediments. Science 284:493-495

Seitzinger SP (1988) Denitrification in freshwater and coastal marine ecosystem: ecological and geochemical significance. Limnol Oceanogr 33:702-724

Sørensen J (1978) Capacity for denitrification and reduction of nitrate to ammonia in a coastal marine sediment. Appl Environ Microbiol 35:301-305

Sørensen J (1987) Nitrate reduction in marine sediment: pathways and interactions with iron and sulfur cycling. Geomicrobiol J 5(3/4):401-421

Tiedje JM, Sexstone AJ, Myrold DD, Robinson JA (1982) Denitrification: ecological niches, competition and survival. Antonie Leeuwenhoek 48:569-583

Tobias CR, Anderson IC, Canuel AC, Macko SA (2001) Nitrogen cycling through a fringing marsh-aquifer ecotone. Mar Ecol Prog Ser 210:25-39

Yoon WB, Benner R (1992) Denitrification and oxygen consumption in sediment of two south Texas estuaries. Mar Ecol Prog Ser 90:157-167

Zimmerman AR, Benner R (1994) Denitrification, nutrient regeneration and carbon mineralization in sediments of Galveston Bay, Texas, USA. Mar Ecol Prog Ser 114:275-288

Submitted: February 28, 2001; Accepted: January 31, 2002

Proofs received from author(s): June 25, 2002 